\title{
Fluorescence in situ hybridization in combination with the comet assay and micronucleus test in genetic toxicology
}

\author{
Galina G Hovhannisyan
}

\begin{abstract}
Comet assay and micronucleus (MN) test are widely applied in genotoxicity testing and biomonitoring. While comet assay permits to measure direct DNA-strand breaking capacity of a tested agent MN test allows estimating the induced amount of chromosome and/or genome mutations. The potential of these two methods can be enhanced by the combination with fluorescence in situ hybridization (FISH) techniques. FISH plus comet assay allows the recognition of targets of DNA damage and repairing directly. FISH combined with MN test is able to characterize the occurrence of different chromosomes in $\mathrm{MN}$ and to identify potential chromosomal targets of mutagenic substances. Thus, combination of FISH with the comet assay or MN test proved to be promising techniques for evaluation of the distribution of DNA and chromosome damage in the entire genome of individual cells. FISH technique also permits to study comet and MN formation, necessary for correct application of these methods. This paper reviews the relevant literature on advantages and limitations of Comet-FISH and MN-FISH assays application in genetic toxicology.
\end{abstract}

\section{Introduction}

A considerable battery of assays exists for the detection of different genotoxic effects of compounds in experimental systems in vitro, or for investigations of exposure to genotoxic agents in vivo. The single cell gel electrophoresis, called shortly 'comet assay', as well as the micronucleus (MN) test are broadly applied test systems to check for genotoxic effects. In addition to classical cytogenetic methods for scoring chromosomal aberrations, fluorescence in situ hybridization (FISH) is used in genetic toxicology for analysis of chromosome damage with increased efficiency and specificity for identifying certain kinds of chromosomal aberrations. The comet assay, MN test and FISH presented in International Programme on Chemical Safety (IPCS) guidelines among the most often studied genotoxicity endpoints for the monitoring of genotoxic effects of carcinogens in humans [1]. Recently FISH technique was successfully combined with comet and MN assays for simultaneously measuring the overall level of DNA and

Correspondence: hovgalina@list.ru

Department of Genetics and Cytology, State University, Biological Faculty, 1 Alex Manoukian Street, Yerevan 375025, Armenia chromosome damage, and localizing of specific genome domains within an individual cell.

\section{Principles and application of the comet assay}

The comet assay is a rapid and very sensitive fluorescent microscopy-based method for measuring DNA damage, protection and repair at the level of individual cells [2-7]. In this assay cells are embedded in agarose, lysed and then electrophoresed. Negatively charged broken DNA strands exit from the lysed cell under the electric field and form a comet with "head" and "tail." The amount of DNA in the tail, relative to the head, is proportional to the amount of strand breaks. The limit of the comet assay sensitivity is approximately 50 strand breaks per diploid mammalian cell [8]. It permits to reveal mainly early, still repairable, moderate DNA damage and can be used in virtually any eukaryotic cell. In order to achieve various objectives, different modifications of the comet assay have been developed. In its alkaline version, which is mainly used, DNA singlestrand breaks, DNA double-strand breaks, alkali-labile sites, and single-strand breaks associated with incomplete excision repair sites cause increased DNA migration [9]. In the neutral variant the DNA molecule itself 
is preserved as a double stranded structure which enables uncovering of double stranded DNA breaks $[10,11]$. Crosslinkage of DNA-DNA/DNA-protein leading to decreased DNA migration can be identified by the failure to detect single-strand breaks that were known to be present [12]. Oxidized purins and pyrimidins, could be revealed by incubating lysed cells with base damage-specific endonucleases before electrophoresis [13]. The comet assay has manifold applications in fundamental research for DNA damage and repair, in genotoxicity testing, human biomonitoring and molecular epidemiology and ecotoxicology $[5,14,15]$.

\section{Principles and application of $\mathrm{MN}$ test}

The MN test is one of the preferred methods for assessing DNA damage at the chromosome level. It permits to measure both chromosome loss and chromosome breakage [16,17]. Metaphase analysis provides the most detailed analysis of numerical and structural chromosome aberrations, however, it is very time consuming and needs highly skilled personnel. The MN assay was developed as a simpler short-term screening test and now accepted as valid alternative to the chromosome aberration assay. In this method, chromosome aberrations are detected indirectly via chromatin loss from the nucleus leading to $\mathrm{MN}$ in the cytoplasm of the cell $[18,19]$. MN are expressed only in dividing cells. Adding to cell cultures cytochalasin- $\mathrm{B}$, an inhibitor of the mitotic spindle that prevents cytokinesis, permits to recognize cells that have completed one nuclear division by their binucleated appearance $[20,21]$. The cytokinesisblock micronucleus (CBMN) assay allows higher precision because the data obtained are not affected by altered cell division kinetics [22]. Recently the CBMN assay has in fact evolved into a "cytome" method for measuring chromosomal instability, DNA repair capacity, nuclear division rate, mitogenic response and occurrence of necrotic and apoptotic cells [23]. The MN test has become one of the most commonly used methods in genotoxicity testing and biomonitoring populations at risk $[15,24,25]$. This test has been recommended for monitoring in product development and regulatory tests of new drugs [26].

\section{Principles and application of FISH technique}

FISH is a powerful technique for localization of specific DNA sequences within interphase chromatin and metaphase chromosomes and the identification of both structural and numerical chromosome changes. The detection of nucleotidic sequences on examined DNA molecule consists in hybridizing a DNA probe to its complementary sequence on chromosomal preparations. Probes are labeled either directly, by incorporation of fluorescent nucleotides, or indirectly, by incorporation of reporter molecules that are subsequently detected by fluorescent antibodies. Probes and targets are finally visualized in situ by microscopy analysis. FISH technique protocols and wide variety of current applications of FISH technology are presented [27-33]. Structural and numerical chromosomal aberrations have been considered important biological end points in genotoxic studies. FISH with chromosome-specific DNA probes has increased the sensitivity and ease of detecting chromosomal aberrations, especially stable chromosomal aberrations. Now FISH is being increasingly utilized in genetic toxicology for the detection of chromosome damage induced in vitro and in vivo by chemical and physical agents [34-37].

\section{Overcoming of limitations of comet and MN assays by FISH}

Compared with other assays, analysis of comets and $\mathrm{MN}$ bring along several advantages, including speed and ease of analysis and no requirement for metaphase cells in MN test and no need for dividing cells in the comet assay. However, results from the comet assay alone reflect only the level of overall DNA damage in single cells. The same is typical for MN test as it does not even permit to distinguish MN containing whole chromosomes from MN containing chromosome fragments. The introduction of FISH [27] in comet and MN assays has allowed adding new abilities and to enhance resolution and validity of these two methods.

FISH permitted to supplement potential of the comet assay with an opportunity to recognize genome regions of interest on comet images. Thus, Comet-FISH is applied for the analysis of damage and repair of different genes, chromosomes and chromosome regions compared to whole genomic DNA within the comet, or visualization of genomic loci in three-dimensional organization of chromatin and elucidation of mechanism of comet formation and DNA organization in comets. By $\mathrm{MN}$ test combined with FISH the genetic contents of the MN can be characterized. The application of FISH probes allows to distinguish $\mathrm{MN}$ originating either from chromosome loss or breakage and to determine the involvement of specific chromosomes and chromosome fragments in $\mathrm{MN}$ formation. Using MN-FISH the clastogenic or aneugenic action of different factors, the chromosomal origin of spontaneous and mutagen-induced $\mathrm{MN}$, and the relative contribution of all chromosomes in $\mathrm{MN}$ formation can be studied.

Therefore, FISH was recognized as a valuable addition to comet and MN assays [38,39]. The simultaneous use of these methodologies will enable to achieve a higher sensitivity for the adequate hazard assessment of mutagens and will lead to a better understanding of the biological mechanisms involved. Literature data 
concerning combined application of FISH with comet and $\mathrm{MN}$ assays in genetic toxicology are discussed in the following.

\section{Comet-FISH}

\section{Methodological aspects of Comet-FISH}

Comet-FISH was first applied in human cells to compare the localization of specific chromosomal domains in native interphase nuclei with their distribution in comet-head and -tail after electrophoreses [40]. As heatdenaturation necessary for FISH is impossible within a comet fixed in low melting point agarose chemical denaturation of the DNA with alkali solutions was introduced [40] and applied in human leukocytes and the cell line HT1376 [41]. Soon thereafter the term "CometFISH" was introduced [42]. Two versions of CometFISH, one based on the alkaline and one on the neutral versions of the comet assay were developed subsequently $[38,43]$. The reliability of Comet-FISH was confirmed in some experiments. It could be shown that in Comet-FISH comparable results to metaphase based molecular cytogenetic approaches are obtained with respect to hybridization sensitivity and reproducibility [44] and the proportion of DNA elements from specific chromosomal domains in comet heads and tails corresponded to the expected localization based on the distribution of cleavage sites for specific endonucleases [45].

Various DNA probes were successfully applied with the comet assay for analysis of damage and repair of specific genome loci (genes, chromosomes and chromosome regions). The size of the region of interest investigated by Comet-FISH varies from gene [46] to whole chromosome [44]. In the comet assay 10 to $800 \mathrm{~kb}$ fragments are analyzed and fragments smaller than $10 \mathrm{~kb}$ might get lost in agarose gel [44]. However, DNA probes smaller than $10 \mathrm{~kb}$ cannot be used also in routine FISH. Results of various FISH probes application with the comet assay is summarized in Table 1.

Microscopic evaluation of the Comet-FISH images includes record of the number of probe signals and their localization on comet. The position of the fluorescence signals indicates whether the sequence of interest lies within the undamaged (head) or within or in the vicinity of a damaged (tail) region of DNA. Repositioning of gene-specific signals from tail to head over the incubation period provides evidence for repair of all the lesions within and around the locus of interest [47]. The level of DNA-damage and -repair in specific domains can be expressed as percent of FISH signals present in head vs. tail [48].

However, doing FISH on comet assay preparations is different from that of routine FISH mainly by the fact that it is performed not on flattened interphase nuclei fixed to a glass slide but on three-dimensional (3-D) preserved ones. This 3-D state reflects to some degree the real organization of chromatin in the living cell. On the other hand, the 3-D shape leads also to serious difficulties in the visualization and scoring of the signals [47]. Thus, analysis of Comet-FISH images is not easy automatized as the individual analysis of each comet is necessary to determine the distribution of signals between head and tail. Nevertheless, it is expected that automated systems for scoring of at least certain kinds of FISH signals might be elaborated in the near future [47].

\section{FISH in elucidation of comets formation}

Although the comet method is very popular, there is still no agreement on how the comet tail is formed. Understanding of comet formation and the factors influencing this process is necessary for the comet assay correct application in genetic toxicology. In the comet assay, cells are electrophoresed in a way that fragmented and relaxed DNA migrates towards anode further than intact DNA, producing a situation resembling a comet. Relaxation of DNA loops was proposed to be the primary basis for comet formation under neutral $[11,49]$ and alkaline [4] conditions. The comet tails obtained after neutral electrophoresis seem to consist of DNA loops which are attached to structures in the nucleus, since the DNA cannot move in the second direction after two-dimensional electrophoresis. Under alkaline electrophoresis conditions, however, the entire comet tail moves in the new electrophoresis direction. Thus, it appears that the alkaline comet tails consist of free DNA fragments [50].

The application of FISH has allowed to explain further aspects of comet formation. An important question is whether the complementary strands within a loop migrate into the tail independently or together upon alkaline denaturation and electrophoresis. Comet-FISH with a probe for the $p 53$ gene was applied to cells that had been damaged by ionizing radiation. The results obtained favored the idea that both strands in a loop migrate into the tail, but separately, even in cases in which one strand is broken and the complementary strand is intact [51].

Before the era of Comet-FISH it was generally accepted that, when single cell gel electrophoreses is performed undamaged DNA remains in the comet head and the fraction of damaged DNA moves to the comet tail. FISH experiments indicated that besides the presence of breaks there are other factors determining the ability of particular DNA-sequences to migrate into the tail. These include the nature of the damage and organization of chromatin [47]. DNA from regions closely and extensively associated with the nuclear matrix, such as replicating DNA, does not move into the tail in standard alkaline comet assay [52]. Furthermore, fragments of 
Table 1 Results of various FISH probes application with the comet assay

\begin{tabular}{|c|c|c|c|}
\hline FISH probes & What is detected & Results and applications & References \\
\hline- & Whole DNA damage and repair & $\begin{array}{l}\text { Genotoxicity testing or biomonitoring of genotoxic } \\
\text { exposure and effect }\end{array}$ & {$[1-15]$} \\
\hline \multirow[t]{3}{*}{ Gene-specific } & $\begin{array}{l}\text { DNA damage and repair within the } \\
\text { vicinity of the gene of interest }\end{array}$ & $\begin{array}{l}\text { Analysis of damage and repair of genes related } \\
\text { with cancer (TP53, KRAS, APC, p53) }\end{array}$ & {$[41,46,51,53-58]$.} \\
\hline & & $\begin{array}{l}\text { Analysis of damage of genes Ret, Ab1 and Trp53 as } \\
\text { biomarker of X-radiation exposure in vivo }\end{array}$ & {$[59]$} \\
\hline & & $\begin{array}{l}\text { Spatial distribution of chromosome-specific DNA } \\
\text { sequences }\end{array}$ & [40] \\
\hline \multirow{2}{*}{$\begin{array}{l}\text { Chromosome locus-specific } \\
\text { (centromere-, telomere- and region- } \\
\text { specific) }\end{array}$} & $\begin{array}{l}\text { DNA damage within the vicinity of } \\
\text { the locus of interest }\end{array}$ & $\begin{array}{l}\text { Analysis of leukaemia-specific chromosome } \\
\text { damage }\end{array}$ & [61] \\
\hline & & $\begin{array}{l}\text { Analysis of sensitivity of telomeres toward } \\
\text { anticancer drugs }\end{array}$ & {$[63-65]$} \\
\hline \multirow[t]{2}{*}{ WCP } & $\begin{array}{l}\text { DNA damage within the } \\
\text { chromosome of interest }\end{array}$ & Distribution of DNA damage in genome & {$[44,60]$} \\
\hline & & $\begin{array}{l}\text { Genetic alterations in carcinogenesis of the upper } \\
\text { aerodigestive tract }\end{array}$ & [62] \\
\hline \multirow[t]{2}{*}{ Selected probes } & Different genomic regions & Transcription-coupled DNA repair & [48] \\
\hline & & Elucidation of comet formation & {$[44-46,51,52]$} \\
\hline
\end{tabular}

gene-poor chromosomes were found more frequently in comet tail of UV-A-irradiated lymphocytes than fragments of gene-rich ones. It was suggested that chromosomes with high gene density are more resistant to DNA-damaging agents [44]. An alternative explanation would be the association of gene-rich regions with sites of transcription, which are located on the surface of the nuclear matrix i.e. in the head of the comet [44]. Similarly, the inability of the DHFR gene and one of ends of MGMT gene to leave the comet head even when the DNA is released from its supercoiling in $\mathrm{CHO}$ cells was explained by their attachment to 'matrix-associated region' [46]. Thus, the data obtained with Comet-FISH contributed in understanding of comet formation and correct interpretation of the comet assay results.

\section{Comet-FISH applications in genetic toxicology}

Combined application of FISH with the comet assay offered the unique possibility to evaluate gene or chromosome damage and repair relative to the overall genome and compare repair rates of individual genes This methodology permits to detect mutagen-induced sitespecific breaks in DNA regions that are relevant for development of various diseases or to recognize genome targets of action of environmental genotoxic agents. Recognition of sites of damage, promotes interpretation of induced in vitro and in vivo genotoxic effects and understanding of their biological impact.

FISH in study of gene damage and repair

Comet-FISH was found to be suitable for detection of DNA damage induced by genotoxic compounds e.g. in colon cancer relevant genes (TP53, KRAS, APC) in primary human colon and colon adenoma LT97 cells. Here this approach really facilitated studies on effects of nutrition-related carcinogens [53-56].

Comet-FISH revealed that strand breaks in the human tumor suppressor $p 53$ gene are repaired very quickly compared with total DNA in RT4 and RT112 bladder carcinoma cells after $\gamma$-irradiation [57] and in mitomycin C-treated RT4 cells [51]. Preferential repair of the p53 locus was shown also in the panel of malignant breast cancer cell lines (MCF-7, MDA-MB-468 and CRL-2336) [58] and in normal lymphocytes [46] following genotoxic treatment.

Comet-FISH is also an effective alternative for measuring transcription-coupled repair (TCR), since the comet assay constitutes an extremely sensitive test for detection of DNA damage and repair by genotoxic agents at subtoxic, physiologically relevant exposures. Application of Comet-FISH for analysis of TCR was discussed elsewhere [48].

Localization and repair rates of DHFR and MGMT genes in $\mathrm{CHO}$ cells and p53 gene in human cells treated with $\mathrm{H}_{2} \mathrm{O}_{2}$ or photosensitizer plus light to induce oxidative damage were monitored using Comet-FISH with oligonucleotide probes for 5' and 3' regions of the genes investigated. $\mathrm{CHO}$ cells shown preferential repair of oxidative damage in the MGMT gene. Strand breaks in the human $p 53$ gene were repaired more rapidly than total DNA. This approach can be applied to other genes treated with a range of damaging agents [46].

It has been shown, that damage of specific genes can be applied as biomarkers of genotoxic exposure. Ret, $A b 1$ and Trp53 genes fragmentation in Comet-FISH 
assay was proposed as in vivo biomarkers of X-radiation exposure in C57BL/6 and CBA/J mice. At the same time the comet assay alone, when applied to the same specimens, produced no significant results because of interindividual variability [59].

\section{FISH in study of chromosome damage}

Comet-FISH in UV-A-irradiated human lymphocytes with whole chromosome painting (wcp), centromere-, telomere- and region-specific probes demonstrated comparably high sensitivity of chromosomes $\mathrm{X}$ and 8 towards UV-A-induced DNA damage [60]. Studying 12 human chromosomes with wcp probes an inverse correlation between chromosomes gene density and their sensitivity towards UV-A-radiation was revealed [44].

Leukaemia-specific chromosome damage (breakage at $5 q 31$ and 11q23) in TK6 lymphoblastoid cells exposed to melphalan, etoposide or hydroquinone was studied using Comet-FISH [61]. Comet-FISH analysis of selected genetic alterations, related with risk factors in carcinogenesis of the upper aerodigestive tract revealed significantly higher benzo[a]pyrene-diolepoxide-induced damage levels in chromosomes 3,5 and 8 compared with chromosome 1 in epithelia cells of patients with squamous cell carcinoma [62].

In our experiments Comet-FISH with telomere-specific peptide nucleic acid (PNA) probes was applied for measuring telomeric DNA sensitivity toward drugs used in cancer therapy in normal human leukocytes [63,64] and in tumor cell lines CCRF-CEM, CHO and HT1080 [65]. Distribution of telomere signals in head and tail of comet, obtained from BLM-treated human leukocytes is presented in Figure 1. Human leukocytes showed preferential cisplatin-DNA crosslinks formation in telomeres and telomere-related regions. Telomeres in $\mathrm{CHO}$ and CCRF-CEM cells were about 2-3 times more sensitive towards BLM than global DNA, while in HT1080 telomeres were less fragile than total DNA. The higher

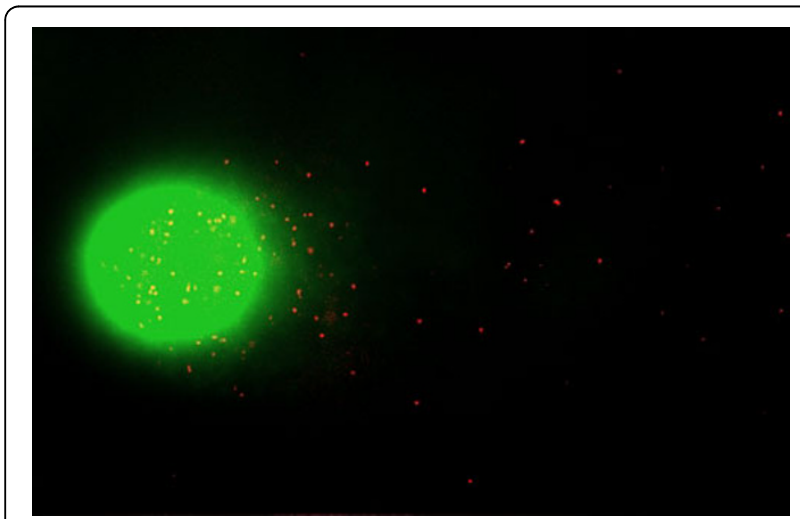

Figure 1 Example of SYBR-green-stained comet image from BLM-treated human leukocytes with telomeric PNA probes indicating the location of telomeric repeat sequences fragility of telomeres compared to the total DNA in non treated human leukocytes [64] reflects findings about concentration of telomeres mainly near the nuclear membrane [40].

\section{MN-FISH}

\section{Methodological aspects of MN-FISH}

FISH analysis of $\mathrm{MN}$ is based on the achievements of interphase FISH [66]. Commercial FISH probes for selective painting of individual chromosomes and specific DNA sequences and software's for image analysis are also suitable for description of $\mathrm{MN}$ composition. A major condition of the quantitative accuracy of the $\mathrm{MN}$ assay is integrity of cell membrane and preservation of the cytoplasm during the cell harvesting [67] while interphase FISH technique allows the destruction of cellular membrane.

MN test was successfully combined with different kinds of DNA probes which recognize centromeres, other chromosome-specific regions and whole chromosomes inside of micronuclei and main nuclei. The analysis of MN combined with centromeric DNA probes for all chromosomes allows discrimination between centromere negative $\mathrm{MN}$ or $\mathrm{MN}$ originating from chromosomal breakage (clastogenic effect) and centromere positive MN or MN containing whole chromosomes (aneugenic effect). Centromere detection can be expected to be more accurate in distinguishing the two main types of MN than anti-kinetochore antibody staining [68] because MN can be formed from entire chromosomes with a disrupted kinetochore [69-71] and show no kinetochore signal.

Application of chromosome-specific centromeric probes permits evaluation of different chromosomes sensitivity toward genotoxic agents. This approach also allows detection of non-disjunctional events (i.e., unequal distribution of homologous chromosomes in daughter nuclei) in binucleated cells [72]. The application of other chromosome region-specific and wcp probes permits evaluation of their participation in formation of spontaneous [73] and induced [74,75] MN. Wcp probes target the euchromatic parts of a chromosome and thereby reveal both whole chromosomes and acentric fragments in $\mathrm{MN}$ [76]. However, they fail to distinguish between an entire chromosome and material from large chromosomal fragments in a particular $\mathrm{MN}$. $\mathrm{MN}$ with whole chromosomes can be discriminated using chromosome-specific centromeric probes on the same cells [74].

However the identification of the chromosome-specific contents of $\mathrm{MN}$ is still very incomplete due to a lack of methods by which the DNA within the MN could be fully investigated. Moreover, the absolute number of fragments enclosed in a MN could not be quantified 
precisely. To our knowledge till now there are no successful attempts of application of interphase chromosome-specific multicolor banding (ICS-MCB) $[27,77,78]$ for analysis of MN contents. Description of the chromosomal contents of $\mathrm{MN}$ has been limited also by the number of simultaneously applied colors and chromosomes evaluated per study. There are only a few studies with analysis of participation of all human chromosomes in $\mathrm{MN}$ formation. Frequency of the presence of all 24 chromosomes in $\mathrm{MN}$ was analyzed by dual-color FISH technique [79]. However, since only two probes on the same slide were applied, this study was time consuming. This approach was also limited in its ability to detect MN that might contain DNA from multiple chromosomes. Spectral karyotyping (SKY) technology [80] offered unique possibility for simultaneous classification of all 24 chromosomes in humans [81]. But this technology is expensive and is limited accessible in MN analysis. Wide introduction of SKY in researches provides a promising opportunity for development of our knowledge about the chromosomal contents of MN. Results of various FISH probes application with the MN test is summarized in Table 2.

\section{FISH in elucidation of $\mathrm{MN}$ formation}

$\mathrm{MN}$ can arise after mitosis from acentric chromosomal fragments or whole chromosomes that are not included in each daughter nucleus. Therefore, in MN test, chromosome aberrations are detected indirectly via DNA loss from the nucleus leading to $\mathrm{MN}$ in the cytoplasm of the cell. FISH technique permits to identify the chromosomal origin of $\mathrm{MN}$ and thus improve our understanding of mechanisms of MN formation.

Anaphase aberrations and $\mathrm{MN}$ formation in woman lymphocytes were compared using pancentromeric and $\mathrm{X}$-chromosome painting probes. It was shown, that micronucleation of the X chromosome in women's lymphocytes is probably the result of frequent lagging behind of the $\mathrm{X}$ chromosome during anaphase [82].

FISH with MN test permits to reveal involvement of different genes in induction of $\mathrm{MN}$ and aneuploidy. CBMN assay with centromere-specific probes in XPDdefective human fibroblast cells demonstrated that the $X P D$ gene product plays a role in the events which protect human cells from the aneugenic effects of chemicals [72]. The data on the contents of MN in blood cells of workers exposed to welding fumes indicated that, detoxification gene GSTM1 positive subjects showed an increased centromere negative $\mathrm{MN}$ frequency and GSTT1 null subjects showed an elevated centromere positive $\mathrm{MN}$ frequency [83].

Thus, MN-FISH combined with analysis of anaphase aberrations and genetic polymorphisms has contributed to the understanding of the processes that accompany the formation of $\mathrm{MN}$.

\section{MN-FISH applications in genetic toxicology}

FISH analysis of MN with application of the different kinds of DNA-probes offered the possibility to precise the nature of genotoxic effects revealed in MN test. Application of MN-FISH in many researches has allowed to reveal the occurrence of different chromosomes in

Table 2 Results of various FISH probes application with MN test

\begin{tabular}{|c|c|c|c|}
\hline FISH probes & What is detected & Results and applications & References \\
\hline \multirow[t]{2}{*}{-} & Both chromosome breakage and loss & $\begin{array}{l}\text { Genotoxicity testing or biomonitoring of genotoxic } \\
\text { exposure and effect }\end{array}$ & {$[16-26]$} \\
\hline & & Discrimination of aneugenic and clastogenic effects in vitro & {$[84-87]$} \\
\hline \multirow[t]{3}{*}{ Centromeric } & MN with whole chromosomes & Discrimination of aneugenic and clastogenic effects in vivo & {$[88-92]$} \\
\hline & & Biomarker of radiation exposure in vivo & {$[93]$} \\
\hline & & $\begin{array}{l}\text { Frequency of occurrence of chromosomes in } \\
\text { spontaneously occurring MN }\end{array}$ & {$[106,107]$} \\
\hline \multirow[t]{2}{*}{$\begin{array}{l}\text { Chromosome-specific } \\
\text { centromeric }\end{array}$} & $\begin{array}{l}\text { Whole chromosomes in MN and non- } \\
\text { disjunctional events }\end{array}$ & $\begin{array}{l}\text { Comparative sensitivity of different chromosomes toward } \\
\text { mutagens }\end{array}$ & {$[96,108,109]$} \\
\hline & & Study of mechanisms of aneuploidy & {$[72,94-98]$} \\
\hline \multirow[t]{2}{*}{$\begin{array}{l}\text { Chromosome-locus- } \\
\text { specific }\end{array}$} & MN with chromosome loci & Nature of genome instability in tumor cells & {$[75]$} \\
\hline & & $\begin{array}{l}\text { Distribution of radiation and chemical mutagen-induced } \\
\text { cytogenetic damage }\end{array}$ & {$[74,79,105,110]$} \\
\hline \multirow[t]{2}{*}{ WCP } & $\begin{array}{l}\text { Both whole chromosomes and acentric } \\
\text { fragments in MN }\end{array}$ & Composition of spontaneous and mutagen-induced MN & {$[39,76,79,81]$} \\
\hline & & $\begin{array}{l}\text { Composition of spontaneous MN in cells of patients with } \\
\text { ICF }\end{array}$ & {$[73]$} \\
\hline Selected probes & Different genomic regions in $\mathrm{MN}$ & Elucidation of MN formation & {$[72,82,83]$} \\
\hline
\end{tabular}


spontaneous and induced $\mathrm{MN}$ and to identify potential chromosomal targets of mutagenic substances. The clastogenic or aneugenic nature of action of many substances has been identified in vitro and in vivo. The characterization of MN contents is crucial for understanding of mechanisms of genotoxicity of chemicals and radiation.

Clastogenic and aneugenic effects detection and analysis of mechanisms of aneuploidy by MN test with centromeric probes

The distinction between the clastogenic and aneugenic effects (leading to structural and numerical chromosome alterations, respectively), by identifying the origin of $\mathrm{MN}$, is important for genotoxicity testing or for biomonitoring of genotoxic exposure and effect. This approach with application of centromeric and chromosome-specific centromeric probes has appeared useful and widely applied in various researches.

Centromere-specific FISH analysis of the MN was applied for in vitro genotoxicity testing in studies of toxins of phytoplankton domoic acid (DA) and okadaic acid (OA) in human intestinal cell line Caco-2 [84], $\mathrm{Al}, \mathrm{Cd}$, $\mathrm{Hg}$, and $\mathrm{Sb}$ salts in human blood cells [85], industrial chemical acrylamide and the traditional Chinese medicine Tripterygium hypoglaucum (level) hutch in mouse NIH 3T3 fibroblasts [86], anti-tumor agents cycloplatam and its parent drugs cisplatin and carboplatin in human lymphocytes [87].

MN-FISH was applied for analysis of genotoxicity in vivo of exposure to nitrous oxide in lymphocytes of operating-room nurses [88] and antihypertensive drug nimodipine in lymphocytes of treated patients [89]. By using FISH analysis with the mouse-satellite DNA-probe it could be shown that nicotine is a clastogen [90], while antitumor drugs topotecan and irinotecan [91] and antibiotic rifampicin [90] are aneugens as well as clastogens in somatic cells in vivo. The results obtained are useful for understanding of possible by-effects of action of medicines.

Environmental lead exposure increases both centromere-positive and centromere-negative $\mathrm{MN}$ in blood lymphocytes of children, however, the contribution of centromere-positive $\mathrm{MN}$ was significantly higher than in the controls [92]. The correlation between centromeric and acentromeric $\mathrm{MN}$ frequencies in chronically irradiated human populations and rate of exposure allows to discuss the possibility of application of centromerespecific FISH with CBMN analysis in biodosimetry [93].

Application of FISH with MN test allows not only to distinguish between clastogenic and aneugenic effects, but also enables to discriminate between two mechanisms of aneuploidy induction: chromosome loss into $\mathrm{MN}$ or chromosome non-disjunction so that one daughter cell becomes trisomic and the other becomes monosomic $[19,72]$. It was shown that chromosome migration impairment would lead to increased frequency of $\mathrm{MN}$ containing a single centromere whereas centrosome amplification would induce $\mathrm{MN}$ with three or more centromeric signals [94].

Studies with chromosome-specific centromeric probes support the observation that chromosome non-disjunction is the major mechanism of spontaneous [72,95] and induced by diethylstilboestrol [72], vincristine and demecolcine [96] and ionizing radiation [97] aneuploidy production. Chromosome loss is main mechanism of okadaic acid-induced aneuploidy [98].

\section{Detection of MN contents with chromosome-specific centromeric probes}

Well known fact of a non-random distribution of chromosome damages arise spontaneously $[99,100]$ and after exposure to chemicals $[101,102]$ or radiation $[103,104]$ can be successfully investigated by evaluation of relative rate of micronucleation of different chromosomes or chromosome fragments $[39,81,105]$.

With application of chromosome-specific centromeric probes in was shown that both the $\mathrm{X}$ and the $\mathrm{Y}$ chromosomes are overrepresented in lymphocyte $\mathrm{MN}$ of men but that the $\mathrm{Y}$ chromosome is overrepresented only in older subjects [106]. Occurrence of acrocentric chromosomes in spontaneous $\mathrm{MN}$ is neither overrepresented nor influenced by age or sex [107].

Treatment of lymphocytes with aneuploidogens vincristine and demecolcine in vitro increased frequency of micronucleation and malsegregation of chromosomes $\mathrm{X}$ and 8 in different age groups of women [96]. Aneuploidy of chromosome 8 was more frequent than aneuploidy of chromosome 7 in human lymphocytes treated with the 1,2,4-benzenetriol in vitro probably as only cells with non-lethal chromosome aberration could survive to be detected [108]. Non-disjunction and micronucleation of $\mathrm{X}$ chromosome was revealed in vitro in human lymphocytes treated with chemotherapeutic agents melphalan, chlorambucil and p-N,N-bis(2-chloroethyl) aminophenylacetic acid [109].

Reasons of preliminary inclusion of some chromosomes in spontaneous and induced $\mathrm{MN}$ require further investigation. But it is known, that chromosome-specific aneuploidy play key roles in the development and progression of cancers. Thus, precise identification of the specific chromosomes and chromosome regions involved in the observed alternations should be continuously important areas for future research.

\section{Detection of MN contents with probes for chromosome regions and wcp}

Analysis of chromosomal contents of spontaneous MN in normal woman lymphocytes using SKY [80] and FISH technologies demonstrated that the vast majority of $\mathrm{MN}$ appears to be derived from a single chromosome as a result of chromosome lagging. SKY analysis showed 
that all of the 23 chromosomes could be present in the $\mathrm{MN}$, overall, the $\mathrm{X}$ chromosome was seen most frequently [81].

In spontaneously arising $\mathrm{MN}$ of blood cells of patients with immunodeficiency, centromeric instability, and facial anomalies syndrome (ICF) chromosome 1 appeared to be present in a higher proportion compared to chromosomes 9 and 16. Chromosome 18, not associated with the ICF syndrome, showed no signal in any of the MN observed [73]. FISH analysis of MN contents in human lymphocytes has shown lack of ethyl methanesulfonateinduced repair in chromosome 1 heterochromatin. This result is clarified frequent involvement of band $1 \mathrm{q} 12$ in chromosome 1 rearrangements in human cancer cells [75].

We studied the involvement of chromosomes 7, 18 and $\mathrm{X}$ in mitomycin $\mathrm{C}$ (MMC)-induced $\mathrm{MN}$ using wcp and chromosome-specific centromere probes. It was shown that X-chromosomal material was over represented in female- and under represented in male-derived $\mathrm{MN}$. MN with centromeric and wcp signals from chromosome $\mathrm{X}$ in MMC-treated human leukocytes is presented in Figure 2. We speculated about a preferred inclusion of the inactive female $\mathrm{X}$ chromosome into $\mathrm{MN}$ [74]. The contribution of different chromosomes in clastogen MMC- and aneugen diethylstilboestrol (DES)induced MN was analysed in human lymphocytes using painting probes for all chromosomes. FISH analysis showed that DNA from chromosomes 9 and 1 was overrepresented in MMC-induced MN. The occurrence of chromosomes in DES-induced $\mathrm{MN}$ is more random than that in MMC-induced MN [79]. Results of application of wcp for chromosomes 1, 7, 11, 14, 17 and 21 with pancentromeric probes in $\mathrm{MN}$ induced by ionizing radiation in human lymphocytes support a random model of radiation-induced cytogenetic damage for the six chromosomes studied [105].

Until now, FISH has not been widely applied in plant mutagenesis because DNA probes required for chromosomes of particular plant species are very limited. The study [110] is a rare example of a detailed identification of the specific chromosomes or chromosome fragments involved in the mutagen-induced $\mathrm{MN}$ in barley cells.

\section{Conclusions}

In summary, combined application of the FISH technique with comet and $\mathrm{MN}$ assays permits to improve the ability of these widely used genotoxicity tests.

Tests for estimation of genotoxicity belong to the express methods and should be easy and rapid in application. These advantages determine some limitations of methods, namely inability to recognize damage of certain loci of genome. $\mathrm{MN}$ and comet assays with application of different kinds of FISH probes offer unique possibility to detect on the same specimen the total DNA and chromosome damage and evaluate damage of specific regions of genome as well.

$\mathrm{MN}$ and comets appear by loss of DNA material from the nucleus in micronuclei and in comet tail, respectively. Therefore, both methods reflect secondary rather than primary effects of DNA damage. FISH analysis of origin and contents of $\mathrm{MN}$ and comets promotes the better understanding of mechanisms of their formation necessary for correct application of methods.

Special modifications for concurrent application of FISH with comet and MN assays were elaborated. It was confirmed that data obtained with FISH on MN and

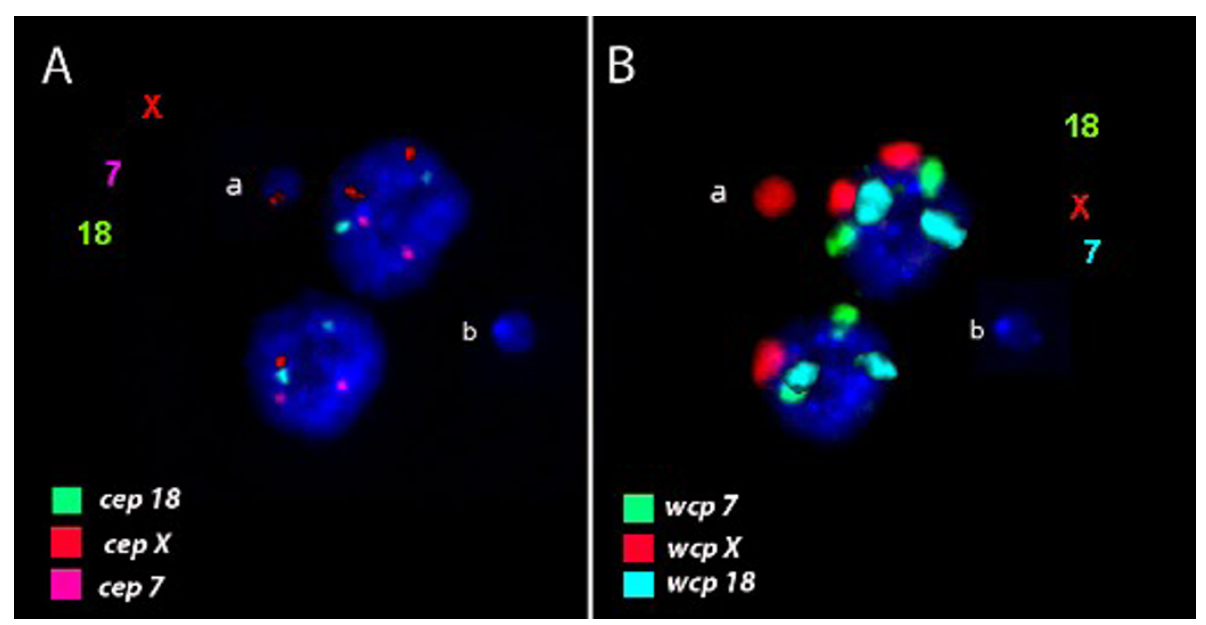

Figure 2 Example of DAPI-stained binucleated cell image from MMC-treated human leukocytes with centromeric (A) and whole chromosome painting (B) probes for chromosomes 7, 18 and $\mathbf{X}$. MN (a) contains centromeric signal from chromosome $X$ in (A) and whole chromosome probe signals from chromosome $X$ in (B). MN (b) did not provide neither centromeric nor wcp signals. 
comets are comparable with results of metaphase and interphase FISH.

Comet-FISH technique permits to gain valuable and reliable information, particularly about DNA damage and repair in general and also in relation to the organization of the nucleus. Some questions relating to the behaviour and organization of DNA within the comet were clarified using FISH technique. Comet-FISH was applied for detection of DNA damage and repair of cancer relevant genes, for measuring transcription-coupled repair, identification of genome targets of action of various genotoxic agents, including anti-tumour preparations.

MN-FISH permits to discriminate aneugenic and clastogenic effect in $\mathrm{MN}$ and to recognize contents of $\mathrm{MN}$. MN-FISH was applied in various researches for elucidation of mechanisms of genomic instability, distribution of chromosome breaks in genome and, to some extent, the etiology of certain human maladies.

Indeed, the available data demonstrate that FISH technique is able to develop the genotoxicity assessment using the comet assay and MN test.

\section{Acknowledgements}

The author is obliged to Prof E. Gebhart (Erlangen, Germany), Dr A. Rapp (Jena, Germany) and Dr T. Liehr (Jena, Germany) for support in realization of researches with Comet-FISH and MN-FISH application and Prof R. Aroutiounian (Yerevan, Armenia) for critical recommendations.

\section{Authors' contributions}

GGH wrote the manuscript. Author read and approved the final manuscript.

\section{Competing interests}

The author declares that they have no competing interests.

Received: 22 June 2010 Accepted: 15 September 2010 Published: 15 September 2010

\section{References}

1. Albertini RJ, Anderson D, Douglas GR, Hagmar L, Hemminki K, Merlo F, Natarajan AT, Norppa H, Shuker DE, Tice R, Waters MD, Aitio A: IPCS guidelines for the monitoring of genotoxic effects of carcinogens in humans. International Programme on Chemical Safety. Mutat Res 2000, 463:111-172.

2. Collins AR, Dobson VL, Dusinska M, Kennedy G, Stetina R: The comet assay: what can it really tell us? Mutat Res 1997, 375:183-193.

3. Tice RR, Agurell E, Anderson D, Burlinson B, Hartmann A, Kobayashi H, Miyamae Y, Rojas E, Ryu JC, Sasaki YF: Single cell gel/comet assay: guidelines for in vitro and in vivo genetic toxicology testing. Environ $\mathrm{Mol}$ Mutagen 2000, 35:206-221.

4. Collins AR: The comet assay for DNA damage and repair: principles, applications, and limitations. Mol Biotechnol 2004, 26:249-261.

5. Wong WWC, Szeto YT, Collins AR, Benzie IFF: THE COMET ASSAY: a biomonitoring tool for nutraceutical research. Current Topics in Nutraceutical Research 2005, 3:1-14.

6. Møller P: The alkaline comet assay: Towards validation in biomonitoring of DNA damaging exposures. Basic Clin Pharmaco Toxicol 2006, 98:336-345.

7. Collins AR, Oscoz AA, Brunborg G, Gaivão I, Giovannelli L, Kruszewski M, Smith CC, ttina R: The comet assay: topical issues. Mutagenesis 2008, 23:143-151.

8. Olive PL, Banáth JP: The comet assay: a method to measure DNA damage in individual cells. Nature Prot 2006, 1:23-29.
9. Singh NP, McCoy MT, Tice RR, Schneider EL: A simple technique for quantitation of low levels of DNA damage in individual cells. Exp Cell Res 1988, 175:184-191.

10. Olive PL, Wlodek D, Banáth JP: DNA double-strand breaks measured in individual cells subjected to gel electrophoresis. Cancer Res 1991, 51:4671-4676.

11. Ostling O, Johanson KJ: Microelectrophoretic study of radiation-induced DNA damages in individual mammalian cells. Biochem Biophys Res Commun 1984, 123:291-298.

12. Merk O, Speit G: Detection of crosslinks with the comet assay in relationship to genotoxicity and cytotoxicity. Environ Mol Mutagen 1999, 33:167-172.

13. Collins AR, Duthie SJ, Dobson VL: Direct enzymic detection of endogenous oxidative base damage in human lymphocyte DNA. Carcinogen 1993, 14:1733-1735.

14. Speit $G$, Hartmann A: The comet assay: a sensitive genotoxicity test for the detection of DNA damage and repair. Methods Mol Biol 2006, 314:275-286.

15. Maluf SW: Monitoring DNA damage following radiation exposure using cytokinesis-block micronucleus method and alkaline single-cell gel electrophoresis. Clinica Chimica Acta 2004, 347:15-24.

16. Fenech M, Holland N, Chang WP, Zeiger E, Bonassi S: The HUman MicroNucleus Project - an international collaborative study on the use of the micronucleus technique for measuring DNA damage in humans. Mutat Res 1999, 428:271-283.

17. Fenech M: The in vitro micronucleus technique. Mutat Res 2000 , 455:81-95

18. Kirsch-Volders M, Sofuni T, Aardema M, Albertini S, Eastmond D, Fenech M, Ishidate M Jr, Kirchner S, Lorge E, Morita T, Norppa H, Surrallés J, Vanhauwaert A, Wakata A: Report from the in vitro micronucleus assay working group. Mutat Res 2003, 540:153-163.

19. Kirsch-Volders M, Vanhauwaert A, De Boeck M, Decordier I: Importance of detecting numerical versus structural chromosome aberrations. Mutat Res 2002, 504:137-148.

20. Fenech M, Morley A: Measurement of micronuclei in lymphocytes. Mutat Res 1985, 147:29-36.

21. Fenech M, Morley A: Solutions to the kinetic problem in the micronucleus assay. Cytobios 1985, 43:233-246.

22. Fenech M: The advantages and disadvantages of the cytokinesis-block micronucleus method. Mutat Res 1997, 392:11-18.

23. Fenech M: Cytokinesis-block micronucleus assay evolves into a "cytome" assay of chromosomal instability, mitotic dysfunction and cell death. Mutat Res 2006, 600:58-66.

24. Mateuca R, Lombaert N, Aka PV, Decordier I, Kirsch-Volders M: Chromosomal changes: induction, detection methods and applicability in human biomonitoring. Biochimie 2006, 88:1515-1531.

25. Hovhannisyan G, Aroutiounian R, Glei M: Butyrate reduces the frequency of micronuclei in human colon carcinoma cells in vitro. Toxicology in Vitro 2009, 23:1028-1033.

26. OECD, Draft New Test Guideline 487: Vitro Micronucleus Test 2004.

27. Liehr T: Fluorescence in situ hybridization (FISH) - Application guide Berlin, Heidelberg: Springer 2009.

28. Nath J, Johnson KL: A review of fluorescence in situ hybridization (FISH): current status and future prospects. Biotech Histochem 2000, 75:54-78.

29. Trask BJ, Allen S, Massa H, Fertitta A, Sachs R, van den Engh G, Wu M: Studies of metaphase and interphase chromosomes using fluorescence in situ hybridization. Cold Spring Harb Symp Quant Biol 1993, 58:767-775.

30. Liehr T, Starke H, Heller A, Kosyakova N, Mrasek K, Gross M, Karst C, Steinhaeuser U, Hunstig F, Fickelscher I, Kuechler A, Trifonov V, Romanenko SA, Weise A: Multicolor fluorescence in situ hybridization (FISH) applied to FISH-banding. Cytogenet Genome Res 2006, 114:240-244.

31. Eastmond DA, Schuler M, Rupa DS: Advantages and limitations of using fluorescence in situ hybridization for the detection of aneuploidy in interphase human cells. Mutat Res 1995, 348:153-62.

32. Levsky JM, Singer RH: Fluorescence in situ hybridization: past, present and future. J Cell Sci 2003, 116:2833-2838.

33. Volpi EV, Bridger JM: FISH glossary: an overview of the fluorescence in situ hybridization technique. Biotechniques 2008, 45:385-409.

34. Natarajan AT: Fluorescence in situ hybridization (FISH) in genetic toxicology. J Environ Pathol Toxicol Oncol 2001, 20:293-298. 
35. Chen $Y$, Jin $C Z$, Zhang $X Q$, Ge SL, Zhang ZY, Xu H, Liu XL, Wu DC, Zhou PK: Seventeen-year follow-up study on chromosomal aberrations in five victims accidentally exposed to several Gy of $60 \mathrm{Co}$ gamma-rays. Radiat Environ Biophys 2009, 48:57-65.

36. Garcia-Sagredo JM: Fifty years of cytogenetics: a parallel view of the evolution of cytogenetics and genotoxicology. Biochim Biophys Acta 2008, 1779:363-375.

37. Natarajan AT, Boei JJ, Darroudi F, Van Diemen PC, Dulout F, Hande MP, Ramalho AT: Current cytogenetic methods for detecting exposure and effects of mutagens and carcinogens. Environ Health Perspect 1996, 104(Suppl 3):445-448.

38. Rapp A, Hausmann M, Greulich KO: The comet-FISH technique: a tool for detection of specific DNA damage and repair. Methods Mol Bio 2005, 291:107-119.

39. Norppa H, Falck GC: What do human micronuclei contain? Mutagenesis 2003, 18:221-233.

40. Santos SJ, Singh NP, Natarajan AT: Fluorescence in situ hybridization with comets. Exp Cell Res 1997, 232:407-411.

41. McKelvey-Martin VJ, Ho ET, McKeown SR, Johnston SR, McCarthy PJ, Rajab NF, Downes CS: Emerging applications of the single cell gel electrophoresis (Comet) assay. I. Management of invasive transitional cell human bladder carcinoma. II. Fluorescent in situ hybridization comets for the identification of damaged and repaired DNA sequences in individual cells. Mutagenesis 1998, 13:1-8.

42. Bock C, Rapp A, Dittmar H, Monajembashi S, Greulic KO: Localization of specific sequences and DNA single-strand breaks in individual UVAirradiated human lymphocytes by COMET FISH. Prog Biomed Optics, SPIE 1999, 3568:207-217.

43. Schlörmann W, Glei M: Comet fluorescence in situ hybridization (CometFISH): detection of DNA damage. Cold Spring Harb Protoc 2009, 5, pdb. prot5220.

44. Rapp A, Bock C, Dittmar H, Greulich KO: UV-A breakage sensitivity of human chromosomes as measured by COMET-FISH depends on gene density and not on the chromosome size. J Photochem Photobiol B 2000, 56:109-117.

45. Menke M, Angelis KJ, Schubert I: Detection of specific DNA lesions by a combination of Comet assay and FISH in plants. Env Mol Mutagenesis 2000, 35:132-138.

46. Horváthová E, Duinská M, Shaposhnikov S, Collins AR: DNA damage and repair measured in different genomic regions using the comet assay with fluorescent in situ hybridization. Mutagenesis 2004, 19:269-276.

47. Shaposhnikov S, Frengen E, Collins AR: Increasing the resolution of the comet assay using fluorescent in situ hybridization - a review. Mutagenesis 2009, 24:383-389.

48. Spivak G, Cox RA, Hanawalt PC: New applications of the Comet assay: Comet-FISH and transcription-coupled DNA repair. Mutat Res 2009, 681:44-50.

49. Afanasieva K, Zazhytska M, Sivolob A: Kinetics of comet formation in single-cell gel electrophoresis: Loops and fragments. Electrophoresis 2010, 31:512-519.

50. Klaude M, Ericson S, Nygren J, Ahnström G: The comet assay: mechanisms and technical considerations. Mutation Res 1996, 363:89-96.

51. McKenna DJ, Gallus M, McKeown SR, Downes CS, McKelvey-Martin VJ: Modification of the alkaline Comet assay to allow simultaneous evaluation of mitomycin C-induced DNA cross-link damage and repair of specific DNA sequences in RT4 cells. DNA Repair 2003, 2:879-890.

52. McGlynn AP, Wasson G, O'Connor J, McKerr G, McKelvey-Martin VJ, Downes CS: The bromodeoxyuridine Comet assay: detection of maturation of recently replicated DNA in individual cells. Cancer Res 1999, 59:5912-5916.

53. Glei M, Hovhannisyan G, Pool-Zobel BL: Use of Comet-FISH in the study of DNA damage and repair: Review. Mutat Res 2009, 681:33-43.

54. Schaeferhenrich A, Beyer-Sehlmeyer G, Festag G, Kuechler A, Haag N, Weise A, Liehr T, Claussen U, Marian B, Sendt W, Scheele J, Pool-Zobel BL: Human adenoma cells are highly susceptible to the genotoxic action of 4-hydroxy-2-nonenal. Mutat Res 2003, 526:19-32.

55. Knobel Y, Weise A, Glei M, Sendt W, Claussen U, Pool-Zobel BL: Ferric iron is genotoxic in non-transformed and preneoplastic human colon cells. Food Chem Toxicol 2007, 45:804-811.

56. Glei M, Schaeferhenrich A, Claussen U, Kuechler A, Liehr T, Weise A, Marian B, Sendt W, Pool-Zobel BL: Comet fluorescence in situ hybridization analysis for oxidative stress-induced DNA damage in colon cancer relevant genes. Toxicol Sci 2007, 96:279-284.

57. McKenna DJ, Rajab NF, McKeown SR, McKerr G, McKelvey-Martin VJ: Use of the Comet-FISH assay to demonstrate repair of the TP53 gene region in two human bladder carcinoma cell lines. Radiat Res 2003, 159:49-56.

58. Kumaravel TS, Bristow RG: Detection of genetic instability at HER-2/neu and p53 loci in breast cancer cells using Comet-FISH. Breast Cancer Res Treat 2005, 91:89-93.

59. Amendola R, Basso E, Pacifici PG, Piras E, Giovanetti A, Volpato C, Romeo G, Ret : Abl1 (cAbl) and Trp53 gene fragmentations in comet-FISH assay act as in vivo biomarkers of radiation exposure in $\mathrm{C} 57 \mathrm{BL} / 6$ and $\mathrm{CBA} / \mathrm{J}$ mice. Radiat Res 2006, 165:553-561.

60. Rapp A, Bock C, Dittmar H, Greulich KO: COMET-FISH used to detect UV-A sensitive regions in the whole human genome and on chromosome 8 . Neplasma 1999, 46:99-101.

61. Escobar PA, Smith MT, Vasishta A, Hubbard AE, Zhang L: Leukaemiaspecific chromosome damage detected by comet with fluorescence in situ hybridization (comet-FISH). Mutagenesis 2007, 22:321-327.

62. Harreus UA, Kleinsasser NH, Zieger S, Wallner B, Reiter M, Schuller $P$, Berghaus A: Sensitivity to DNA-damage induction and chromosomal alterations in mucosa cells from patients with and without cancer of the oropharynx detected by a combination of Comet assay and fluorescence in situ hybridization. Mutat Res 2004, 563:131-138.

63. Arutyunyan R, Gebhart E, Hovhannisyan G, Greulich KO, Rapp A: CometFISH using peptide nucleic acid probes detects telomeric repeats in DNA damaged by bleomycin and mitomycin $C$ proportional to general DNA damage. Mutagenesis 2004, 19:403-408.

64. Arutyunyan R, Rapp A, Greulich KO, Hovhannisyan G, Gebhart E: Fragility of telomeres after bleomycin and cisplatin combined treatment measured in human leukocytes with the comet-FISH technique. Exp Oncol 2005, 27:38-42.

65. Hovhannisyan G, Rapp A, Arutyunyan R, Greulich KO, Gebhart E: Cometassay in combination with PNA-FISH detects mutagen-induced DNA damage and specific repeat sequences in the damaged DNA of transformed cells. Int J Mol Med 2005, 15:437-442.

66. lourov IY, Vorsanova SG, Soloviev IV, Yurov YB: Interphase FISH: detection of intercellular genomic variations and somatic chromosomal mosaicism. In Fluorescence in situ hybridization (FISH) - Application guide. Edited by: Liehr T. Berlin, Heidelberg: Springer Verlag; 2009:301-311.

67. Lee TK, Wiley AL Jr, Means JA, Biggs L: Preservation of cytoplasm in the human lymphocyte micronucleus assay. Mutagenesis 1994, 9:559-562.

68. Schuler M, Rupa DS, Eastmond DA: A critical evaluation of centromeric labeling to distinguish micronuclei induced by chromosomal loss and breakage in vitro. Mutat Res 1997, 392:81-95.

69. Hando JC, Nath J, Tucker JD: Sex chromosomes, micronuclei and aging in women. Chromosoma 1994, 103:186-192.

70. Hando JC, Tucker JD, Davenport M, Tepperberg J, Nath J: X chromosome inactivation and micronuclei in normal and Turner individuals. Hum Genet 1997, 100:624-628.

71. Nath J, Tucker JD, Hando JC: Y chromosome aneuploidy, micronuclei, kinetochores and aging in men. Chromosoma 1995, 103:725-731.

72. Parry EM, Parry JM, Corso C, Doherty A, Haddad F, Hermine TF, Johnson G, Kayani M, Quick E, Warr T, Williamson J: Detection and characterization of mechanisms of action of aneugenic chemicals. Mutagenesis 2002, 17:509-521.

73. Stacey M, Bennett MS, Hulten M: FISH analysis on spontaneously arising micronuclei in the ICF syndrome. J Med Genet 1995, 32:502-508.

74. Hovhannisyan GG, Mkrtchyan H, Liehr T, Aroutiounian R: Involvement of chromosomes 7, 18 and $\mathrm{X}$ in mitomycin C-induced micronuclei. Balk J Med Genet 2008, 11:45-50.

75. Surralles J, Darroudi F, Natarajan AT: Low level of DNA repair in human chromosome 1 heterochromatin. Genes Chr Cancer 1997, 20:173-184.

76. Fauth $\mathrm{E}$, Scherthan $\mathrm{H}$, Zankl $\mathrm{H}$ : Frequencies of occurrence of all human chromosomes in micronuclei from normal and 5-azacytidine-treated lymphocytes as revealed by chromosome painting. Mutagenesis 1998, 13:235-241.

77. lourov IY, Liehr T, Vorsanova SG, Kolotii AD, Yurov YB: Visualization of interphase chromosomes in postmitotic cells of the human brain by multicolour banding (MCB). Chromosome Res 2006, 14:223-229. 
78. lourov IY, Liehr T, Vorsanova SG, Yurov YB: Interphase chromosome specific multicolor banding (ICS-MCB): a new tool for analysis of interphase chromosomes in their integrity. Biomol Eng 2007, 24:415-417.

79. Fauth $\mathrm{E}$, Scherthan $\mathrm{H}$, Zank $\mathrm{H}$ : Chromosome painting reveals specific patterns of chromosome occurrence in mitomycin C- and diethylstilboestrol-induced micronuclei. Mutagenesis 2000, 15:459-467.

80. Schröck E, du Manoir S, Veldman T, Schoell B, Wienberg J, FergusonSmith MA, Ning Y, Ledbetter DH, Bar-Am I, Soenksen D, Garini Y, Ried T: Multicolor spectral karyotyping of human chromosomes. Science 1996, 273:494-497.

81. Leach NT, Jackson-Cook C: The application of spectral karyotyping (SKY) and fluorescent in situ hybridization (FISH) technology to determine the chromosomal content(s) of micronuclei. Mutat Res 2001, 495:11-19.

82. Catalán J, Falck GC, Norppa H: The X chromosome frequently lags behind in female lymphocyte anaphase. Am J Hum Genet 2000, 66:687-691.

83. larmarcovai G, Sari-Minodier I, Orsière T, De Méo M, Gallice P, Bideau C, Iniesta D, Pompili J, Bergé-Lefranc $U$, Botta A: A combined analysis of XRCC1, XRCC3, GSTM1 and GSTT1 polymorphisms and centromere content of micronuclei in welders. Mutagenesis 2006, 21:159-165.

84. Carvalho PS, Catia R, Moukha S, Matias WG, Creppy EE: Comparative study of domoic acid and okadaic acid induced chromosomal abnormalities in the CACO-2 cell line. Int J Environ Res Public Health 2006, 3:4-10.

85. Migliore L, Cocchi L, Nesti C, Sabbioni E: Micronuclei assay and FISH analysis in human lymphocytes treated with six metal salts. Environmental and Molecular Mutagenesis 1999, 34:279-284.

86. Jie YM, Jia C: Chromosomal composition of micronuclei in mouse $\mathrm{NIH}$ 3T3 cells treated with acrylamide, extract of Tripterygium hypoglaucum (level) hutch, mitomycin C and colchicine, detected by multicolor FISH with centromeric and telomeric DNA probes. Mutagenesis 2001, 16:145-149.

87. Nersesyan A, Perrone E, Roggieri P, Bolognesi C: Cytogenetic toxicity of cycloplatam in human lymphocytes: detection by the micronucleus test and fluorescence in situ hybridization. Anti-Cancer Drugs 2006, 17:289-295.

88. Lewinska D, Stepnik M, Krajewski W, Arkusz J, Stanczyk M, Wronska-Nofer T: Increased incidence of micronuclei assessed with the micronucleus assay and the fluorescence in situ hybridization (FISH) technique in peripheral blood lymphocytes of nurses exposed to nitrous oxide. Mutat Res 2005, 581:1-9.

89. Télez M, Martínez B, Criado B, Ortega B, Peñagarikano O, Flores P, OrtizLastra E, Arrieta I: Evaluation of the cytogenetic damage induced by the antihypertensive drug nimodipine in human lymphocytes. Mutagenesis 2001, 16:345-351.

90. Attia SM, Aleisa AM, Bakheet SA, Al-Yahya AA, Al-Rejaie SS, Ashour AE, AlShabanah OA: Molecular cytogenetic evaluation of the mechanism of micronuclei formation induced by camptothecin, topotecan, and irinotecan. Environ Mol Mutagen 2009, 50:145-151.

91. Attia SM: Chromosomal composition of micronuclei in mouse bone marrow treated with rifampicin and nicotine, analyzed by multicolor fluorescence in situ hybridization with pancentromeric DNA probe. Toxicology 2007, 235:112-118

92. Kapka L, Baumgartner A, Siwińska E, Knudsen LE, Anderson D, Mielzyńska D: Environmental lead exposure increases micronuclei in children. Mutagenesis 2007, 22:201-207.

93. Chang WP, Hsieh WA, Chen DP, Lin YP, Hwang JS, Hwang JJ, Tsai MH, Hwang BF: Change in centromeric and acentromeric micronucleus frequencies in human populations after chronic radiation exposure. Mutagenesis 1999, 14:427-432.

94. larmarcovai G, Botta A, Orsiere T: Number of centromeric signals in micronuclei and mechanisms of aneuploidy. Mini-review. Toxicology Letters 2006, 166:1-10.

95. Zijno A, Marcon F, Leopardi P, Crebelli R: Simultaneous detection of $\mathrm{X}$-chromosome loss and non-disjunction in cytokinesis-blocked human lymphocytes by in situ hybridisation with a centromeric DNA probe; implications for the human lymphocyte in vitro micronucleus assay using cytochalasin B. Mutagenesis 1994, 9:225-232.

96. Bakou K, Stephanou G, Andrianopoulos C, Demopoulos NA: Spontaneous and spindle poison-induced micronuclei and chromosome nondisjunction in cytokinesis-blocked lymphocytes from two age groups of women. Mutagenesis 2002, 17:233-239.

97. Touil N, Elhajouji A, Thierens H, Kirsch-Volders M: Analysis of chromosome loss and chromosome segregation in cytokinesis-blocked human lymphocytes: non-disjunction is the prevalent mistake in chromosome segregation produced by low dose exposure to ionizing radiation. Mutagenesis 2000, 15:1-7.

98. Hégarat LL, Orsière T, Botta A, Fessard V: Okadaic acid: chromosomal nondisjunction analysis in human lymphocytes and study of aneugenic pathway in CHO-K1 cells. Mutat Res 2005, 578:53-63.

99. Starke H, Seidel J, Henn W, Reichardt S, Volleth M, Stumm M, Behrend C, Sandig KR, Kelbova C, Senger G, Albrecht B, Hansmann I, Heller A, Claussen $U$, Liehr T: Homologous sequences at human chromosome 9 bands $\mathrm{p} 12$ and q13-21.1 are involved in different patterns of pericentric rearrangements. Europ J Hum Genet 2002, 10:790-800.

100. Kowalczyk M, Srebniak M, Tomaszewska A: Chromosome abnormalities without phenotypic consequences. J App/ Genet 2007, 48:157-166.

101. Meyne J, Lockhart LH, Arrighi FE: Nonrandom distribution of chromosomal aberrations induced by three chemicals. Mutat Res 1979, 63:201-209.

102. Savage JR, Reddy KS: On the localization of mitomycin C-induced aberrations in normal human and Fanconi's anaemia cells. Mutat Res 1987, 178:65-71.

103. Knehr S, Zitzelsberger H, Braselmann H, Nahrstedt U, Bauchinger M: Chromosome analysis by fluorescence in situ hybridization: further indications for a non-DNA-proportional involvement of single chromosomes in radiation-induced structural aberrations. Int J Radiat Biol 1996, 70:385-392.

104. Barquinero JF, Knehr S, Braselmann H, Figel M, Bauchinger M: DNAproportional distribution of radiation-induced chromosome aberrations analysed by fluorescence in situ hybridization painting of all chromosomes of a human female karyotype. Int J Radiat Biol 1998, 74:315-323.

105. Fimognari C, Sauer-Nehls S, Braselmann H, Nüsse M: Analysis of radiationinduced micronuclei by FISH using a combination of painting and centromeric DNA probes. Mutagenesis 1997, 12:91-95.

106. Catalán J, Autio K, Kuosma E, Norppa H: Age-dependent inclusion of sex chromosomes in lymphocyte micronuclei of man. Am J Hum Gene 1998 63:1464-1472.

107. Scarpato R, Landini E, Miglore L: Acrocentric chromosome frequency in spontaneous human lymphocyte micronuclei, evaluated by dual-colour hybridization, is neither sex- nor age-related. Mutat Res 1996, 373:195-204.

108. Chung HW, Kang SJ, Kim SY: A combination of the micronucleus assay and a FISH technique for evaluation of the genotoxicity of 1,2,4benzenetriol. Mutat Res 2002, 516:49-56.

109. Efthimiou M, Andrianopoulos C, Stephanou G, Demopoulos NA, Nikolaropoulos SS: Aneugenic potential of the nitrogen mustard analogues melphalan, chlorambucil and p-N,N-bis(2-chloroethyl) aminophenylacetic acid in cell cultures in vitro. Mutat Res 2007, 617:125-137.

110. Juchimiuk J, Hering B, Maluszynska J: Multicolour FISH in an analysis of chromosome aberrations induced by $\mathrm{N}$-nitroso-N-methylurea and maleic hydrazide in barley cells. J App/ Genet 2007, 48:99-106.

doi:10.1186/1755-8166-3-17

Cite this article as: Hovhannisyan: Fluorescence in situ hybridization in combination with the comet assay and micronucleus test in genetic toxicology. Molecular Cytogenetics 2010 3:17

\section{Submit your next manuscript to BioMed Central and take full advantage of:}

- Convenient online submission

- Thorough peer review

- No space constraints or color figure charges

- Immediate publication on acceptance

- Inclusion in PubMed, CAS, Scopus and Google Scholar

- Research which is freely available for redistribution 